\title{
DHPLC Elution Patterns of VDR PCR Products Can Predict Prostate Cancer Susceptibility in African American Men
}

\author{
ROBERT L. COPELAND ${ }^{1,2}$, DESTA BEYENE ${ }^{2}$, VICTOR APPREY ${ }^{3}$, MOHAMMAD R. DAREMIPOURAN ${ }^{2}$, \\ TAMMEY J. NAAB ${ }^{4}$, OLAKUNLE O. KASSIM ${ }^{5}$ and YASMINE M. KANAAN ${ }^{2,5}$ \\ ${ }^{1}$ Department of Pharmacology, Howard University, Washington, DC, U.S.A.; \\ ${ }^{2}$ Cancer Center, Howard University, Washington, DC, U.S.A.; \\ ${ }^{3}$ Department of Community and Family Medicine, Howard University, Washington, DC, U.S.A.; \\ ${ }^{4}$ Department of Pathology, Howard University, Washington, DC, U.S.A.; \\ ${ }^{5}$ Department of Microbiology, Howard University, Washington, DC, U.S.A.
}

\begin{abstract}
Background/Aim: Denaturing high-performance liquid chromatography (DHPLC) is a technique that is used to detect mutations. The aim of the present study was to determine whether DHPLC elution patterns of vitamin D receptor (VDR) gene PCR products can serve as indicators of susceptibility to prostate cancer ( $\mathrm{PCa}$ ) risk. Materials and Methods: DNA samples of PCa cases and controls were screened for mutations and/or polymorphisms in coding exons of VDR gene using DHPLC analysis. Logistic regression, phi-coefficient $(\phi)$, and Backward Wald models were used to analyze the data. Results: Similar elution patterns of exons 1, 6, 7 and 9 along with higher prevalence of heteroduplex DNA were observed in PCa samples than in controls. Exons 4 and 8 had highly significant protective effects $(p<0.05)$. Whereas, exons 5,7 , and 9 were perfectly positively correlated with $\mathrm{PCa}$ risk $(\phi=1)$, thus presenting candidate exons significantly associated with susceptibility to PCa. Conclusion: DHPLC elution patterns of the selected exons could be useful to predict susceptibility to develop PCa.
\end{abstract}

Prostate cancer $(\mathrm{PCa})$ is one of the most commonly diagnosed forms of cancer among men in the developed world $(1,2)$. In the United States, it is the second leading cause of death in males. In 2014, it was estimated that 161,360 men were

This article is freely accessible online.

Correspondence to: Yasmine Kanaan, Department of Microbiology, Cancer Canter, College of Medicine, Howard University $520 \mathrm{~W}$ Street, NW, Washington D.C., 20059, U.S.A. Tel: +1 2028069540, Fax: +1 2026671686, e-mail: ymkanaan@ howard.edu

Key Words: Prostate cancer, vitamin D, vitamin D receptor gene, African American men. diagnosed and 26,730 men died of PCa in the United States (3). There are well-established risk-factors such as genetic pre-disposition, age, ethnicity, family history, diet and environmental that contribute to the etiology of $\mathrm{PCa}(4,5)$.

Epidemiological studies suggest that $\mathrm{PCa}$ risk is determined by interactions between environment and genetic predisposition (6-8). There is accumulating evidence that vitamin D may play an important role in the occurrence and progression of prostate cancer. Vitamin D deficiency is widespread throughout the United States and the world. The suggestion has been forwarded that high incidence of prostate cancer in African American men might be related to the deficiency of vitamin D. Therefore, vitamin D deficiency has become a public health concern especially in the African American population in the United States. Sunlight exposure may increase vitamin D synthesis in the skin and is thought to provide protection against prostate cancer (8-11).

Since genetic predisposition is considered a major risk factor, there are many studies suggesting an association between vitamin $\mathrm{D}$ receptor $(V D R)$ gene polymorphisms and the development of PCa (12-20). Due to the abundance of $V D R$ polymorphisms in the human genome as well as their high frequency in the human population, they have often been studied with the aim of explaining variations in the risk for PCa $(21,22)$. Most of the published studies utilized different single nucleotides polymorphisms (SNPs) detection methods, such as TaqMan ${ }^{\circledR}$ SNP Genotyping Assays, polymerase chain reaction restriction fragment length polymorphism (PCRRFLP), Illumina Human arrays and denaturing highperformance liquid chromatography (DHPLC) techniques.

DHPLC has been described as a method for screening DNA samples by comparing two or more chromosomes as a mixture of denatured and reannealed PCR amplicons. When the PCR product is heated and then slowly cooled, the DNA strands separate and randomly reanneal to form a mixture of three 
Table I. List of forward and reverse primers used for PCR amplification of the exons 1-9 of vitamin D receptor gene.

\begin{tabular}{|c|c|c|c|}
\hline Exon & Region length (bp) (chromosomal location)* & Fragment length (bp) & Primer sequence \\
\hline Exon 1 & $244(47882608-47882851)$ & 230 & $\begin{array}{c}\text { 5' CGTGCCCACTTCCTTAGAGACTG 3' } \\
\text { 5' CCACCACCTTCTTATGCCCCT 3' }\end{array}$ \\
\hline Exon 2 & $338(47878917-47879254)$ & 396 & $\begin{array}{l}\text { 5' GATGCCCACCCTTGCTGAG 3' } \\
\text { 5' TGCTTCTTCTCCCTCCCTTTC 3' }\end{array}$ \\
\hline Exon 3 & $307(47864938-47865244)$ & 395 & $\begin{array}{l}\text { 5' } \text { TCCGTGATGACAGGGTGAGG } 3 \text {, } \\
\text { 5' TACAGAGGAAGGGCAGGCAGA } 3\end{array}$ \\
\hline Exon 4 & $494(47857387-47857880)$ & 348 & $\begin{array}{l}\text { 5' CTTCCTTTTCACCATAGCAAACCC 3, } \\
\text { 5' CGTCCCTACCCCAGTTCTGTTC 3' }\end{array}$ \\
\hline Exon 5 & $314(47857040-47857353)$ & 349 & $\begin{array}{c}\text { 5' GCCTTCCTGTAGACCTTCCTCAA 3' } \\
\text { 5' ACCTCCTTCCATCCAGCAGC 3' }\end{array}$ \\
\hline Exon 6 & $444(47855490-47855933)$ & 333 & $\begin{array}{l}\text { 5' ACCTGTGGAGTCACTGTGGGATTC3' } \\
\text { 5' AGCCTGCGTGACAGAGCAAGA 3' }\end{array}$ \\
\hline Exon 7 & $434(47846537-47846970)$ & 403 & $\begin{array}{l}\text { 5' GAACACTCTTGTCCCTTCCAGCC } 3 \text {, } \\
5 \text {, TCTCTCCCTGTTGGTGCCTAACTC } 3\end{array}$ \\
\hline Exon 8 & $348(47846266-47846613)$ & 353 & $\begin{array}{c}\text { 5' AGATTCTGGCTCCACCCGTC 3' } \\
\text { 5' CAGCAGGTCTTTGTCCTTCATACTC3 }\end{array}$ \\
\hline Exon 9 & $525(47844654-47845178)$ & 402 & $\begin{array}{l}\text { 5' AGTCACTGGAGGGCTTTGGG 3', } \\
\text { 5' TGAGGAGGGCTGCTGAGTAGC 3' }\end{array}$ \\
\hline
\end{tabular}

*Chromosomal locations and exon sequences were obtained from UCSC database. (https://www.ncbi.nlm.nih.gov/ genome/gdv/browser/?context=gene\&acc=7421). For accuracy, the primer sequences were checked using USSC In-Silico PCR tool (https://genome.ucsc.edu/cgi-bin/hgPcr). bp, Base pair.

species: a mutant homoduplex, a heteroduplex, and a wildtype homoduplex. This reveals the presence of a mutation by the differential retention of homo- and heteroduplex DNA on reversed-phase chromatography supports under partial denaturation (http://www.transgenomic.com/). Individuals who are heterozygous in a single-nucleotide mutation or polymorphism have a 1:1 ratio of wild type and mutant DNA. The heteroduplex DNA fragments form as a result of base pairing of the single-stranded mutated DNA with singlestranded wild type DNA. Heteroduplex profiles are easily distinguished from homoduplex peaks and thereby provide a reliable means for mutation scanning and discovery (23).

This is the first study to investigate the association of the DHPLC elution patterns (homoduplex, heteroduplex) of PCR products corresponding to $V D R$ coding exons with PCa risk in high-risk population of African American men. Therefore, we have screened a total of 183 DNA samples of PCa cases and controls for the detection of mutations and /or polymorphisms in all coding exons of VDR using the DHPLC technique. Furthermore, we investigated whether a specific elution pattern, age, prostate-specific antigen (PSA) level and family history might exhibit a greater or less association with PCa risk.

\section{Materials and Methods}

Study population. The study cohort consisted of 91 AfricanAmerican men aged more than 40 years old from the Washington DC area with histologically diagnosed adenocarcinoma of the prostate, PSA of more than $3.5 \mathrm{ng} / \mathrm{ml}$, and a positive digital rectal examination (DRE). From our previous studies $(8,24)$, we have also identified 92 age- and ethnicity- matched (African-American) healthy individuals (control group) who were regularly screened, with PSA levels of less than $3.5 \mathrm{ng} / \mathrm{ml}$, normal DRE and with no history of prostate cancer among first-degree relatives. PSA values were obtained at the time of diagnosis for cases and at the time of study enrollment for the control group. The study was approved by the Howard University Institutional Review Board (IRB-02-MED42) and signed informed consent forms have been obtained from each participant. Detailed information about demographics and medical history has previously been described $(8,24)$.

DNA extraction and PCR. Genomic DNA was extracted using the QIAmp DNA Blood Maxi Kit (Qiagen, Inc., Valencia, CA) according to manufacturer's instructions. Different primer sets for exon (E1-E9) fragments (Table I) were used for PCR amplification. The VDR chromosome location is chr12:47,831,537-47,953,048. (http://genome.ucsc.edu/cgi-bin/hgTracks?db=hg38\&lastVirtMode Type $=$ default $\&$ lastVirtModeExtraState $=\&$ virtModeType $=$ default $\& v i$ rtMode $=0 \&$ non VirtPosition $=\&$ position $=\operatorname{chr} 12 \% 3 \mathrm{~A} 47831537-$ 47953048\&hgsid=602911891_He501FkDr5dXtxf5kcZnwFb5BeDu).

PCR was performed in a total volume of $25 \mu 1$, containing $30 \mathrm{ng}$ of genomic DNA as template, 1X PCR buffer II, 20 pmole each of exon specific forward and reverse primers (Table I), $2 \mathrm{mM} \mathrm{MgCl} 2$, $0.2 \mathrm{mM}$ dNTP mix (Applied Biosystems, Foster City, CA) and $2 \mu \mathrm{l}$ AmpliTaq Gold ${ }^{\circledR}$ DNA polymerase (Applied Biosystems, Foster City, CA). PCR was performed in an AmpGene 9700 thermal cycler (Perkin-Elmer 600, Foster City, CA), under the conditions described in Table II. Crude PCR products were checked by $2 \%$ (wt/vol) agarose gel electrophoresis before DHPLC analysis, to ensure the absence of non-specific bands, which could lead to artificial heteroduplex conformation. Crude PCR products were subjected to 
Table II. Alternative PCR conditions that were used for the improvement of the PCR protocol in DHPLC analysis.

$94^{\circ} \mathrm{C}$ for $20 \mathrm{~s}$; exon specific temperature ${ }^{\circ} \mathrm{C}$ for $40 \mathrm{~s}$ and

$72^{\circ} \mathrm{C}$ for $20 \mathrm{~s}$ for 5 cycles at each increment.

$94^{\circ} \mathrm{C}$ for $20 \mathrm{~s}$; optimum temperature ${ }^{\circ} \mathrm{C}$ for $40 \mathrm{~s}$ and $72^{\circ} \mathrm{C}$ for $20 \mathrm{~s}$ for 35 cycles

\begin{tabular}{lc}
\hline$V D R$ exons & Increment annealing temperature $\left({ }^{\circ} \mathrm{C}\right)$ \\
\hline Exon 1 & $53.6,55.6,57.6,59.6$ \\
Exon 2 & $54.9,56.9,58.9,60.9$ \\
Exon 3 & $54.7,56.7,58.7,60.7$ \\
Exon 4 & $55.57,59,61$ \\
Exon 5 & $53.6,55.6,57.6,59.6$ \\
Exon 6 & $52.5,54.5,56.5,58.5$ \\
Exon 7 & $53.8,55.8,57.8,59.8$ \\
Exon 8 & $54.6,56.6,58.6,60.6$ \\
Exon 9 & $56.1,58.1,60.1,62.1$ \\
\hline
\end{tabular}

an additional $10 \mathrm{~min}$ at $95^{\circ} \mathrm{C}$ denaturing step, followed by $10 \mathrm{~min}$ at room temperature for reannealing prior to analysis.

DHPLC. DHPLC was used in order to detect mutations and /or polymorphisms in $V D R$ gene. DHPLC was carried out on an automated DHPLC instrument (WAVE ${ }^{\circledR}$ DNA Fragment Analysis System, Transgenomic, Omaha, NE) equipped with a DNASep column (Transgenomic Inc., San Jose, CA). The cartridge is packed with $\mathrm{C} 18$ alkalylated, polystyrene-divinylbenzene polymeric beads that allow analysis under a wide range of $\mathrm{pH}$ and temperature conditions. DHPLC was performed according to the pre-set conditions including: an initial gradient of $45 \%$ buffer A [0.1 M triethyl-ammonium acetate (TEAA) solution, $\mathrm{pH} 7.0]$ and $55 \%$ buffer B (0.1 M TEAA containing 25\% acetonitrile, $\mathrm{pH} 7.0)$, followed by a final gradient of $36 \%$ buffer $\mathrm{A}$ and $64 \%$ buffer B, using an acquisition time of $8.7 \mathrm{~min}$. PCR products $(25 \mu \mathrm{l})$ were eluted at a $0.9 \mathrm{ml} / \mathrm{min}$ flow rate. The start- and end-points of the gradient were adjusted according to the size of the PCR products using an algorithm provided by the WAVEMakerTM system control software version 1.5.4 (Transgenomic Inc., San Jose, CA). The temperature required for successful resolution of heteroduplex molecules was determined by use of the DHPLC melting algorithm and pretesting of several temperatures.

Statistical analyses. Phi-coefficient $(\phi)$ analysis was used to study the correlation among the VDR exons in relation to PCa. Logistic regression was used to examine the association between each $V D R$ exon, as an independent variable, and $\mathrm{PCa}$ as the dependent variable. The results were further investigated using logistic regression model with Backward elimination to examine whether the effect of any of the exons (E) is modulated by another factor (e.g. Age, PSA level, family history). In particular, we assessed selected "E4 x E7"; "E4 x E7 x age"; "E4 x E7 x age x PSA"; and "E4 x E7 x age x PSA x family history" interactions in 4 models (Model, 1, Model 2, Model 3, and Model 4; respectively) that may include $\mathrm{PCa}$ as a factor. A $p$-value $>0.05$ was considered as statistically significant (SPSS IBM ver 23).
Table III. Elution profiles associated with the DHPLC analysis of PCR amplicons corresponding to VDR exons, for control and PCa DNA samples.

\begin{tabular}{|c|c|c|c|}
\hline Exons & $\begin{array}{l}\text { Homoduplex } \\
\text { sample number }\end{array}$ & $\begin{array}{l}\text { Heteroduplex } \\
\text { sample number }\end{array}$ & $\begin{array}{c}\text { Total } \\
\text { number }\end{array}$ \\
\hline \multicolumn{4}{|l|}{ Exon 1} \\
\hline Control & 60 & 33 & 93 \\
\hline Cases & 54 & 37 & 91 \\
\hline \multicolumn{4}{|l|}{ Exon 2} \\
\hline Control & 76 & 17 & 93 \\
\hline Cases & 86 & 5 & 91 \\
\hline \multicolumn{4}{|l|}{ Exon 3} \\
\hline Control & 72 & 21 & 93 \\
\hline Cases & 90 & 1 & 91 \\
\hline \multicolumn{4}{|l|}{ Exon 4} \\
\hline Control & 27 & 66 & 93 \\
\hline Cases & 63 & 28 & 91 \\
\hline \multicolumn{4}{|l|}{ Exon 5} \\
\hline Control & 64 & 29 & 93 \\
\hline Cases & 70 & 21 & 91 \\
\hline \multicolumn{4}{|l|}{ Exon 6} \\
\hline Control & 91 & 2 & 93 \\
\hline Cases & 86 & 5 & 91 \\
\hline \multicolumn{4}{|l|}{ Exon 7} \\
\hline Control & 57 & 36 & 93 \\
\hline Cases & 51 & 40 & 91 \\
\hline \multicolumn{4}{|l|}{ Exon 8} \\
\hline Control & 27 & 66 & 93 \\
\hline Cases & 63 & 28 & 91 \\
\hline \multicolumn{4}{|l|}{ Exon 9} \\
\hline Control & 51 & 42 & 93 \\
\hline Cases & 45 & 91 & \\
\hline
\end{tabular}

Homoduplex, Single peak; Heteroduplex, double or more peaks.

\section{Results}

The elution patterns of VDR PCR products and their association with PCa risk. We have screened a total of 183 DNA samples of PCa cases and controls for mutations and SNPs detection in all coding exons of VDR using DHPLC analysis. The elution patterns associated with the DHPLC analysis of PCR amplicons containing $V D R$ exons were further investigated to examine whether a specific elution pattern, age, PSA level and family history may exhibit a greater or less PCa risk association.

The differential retention of homoduplex (single peak) and heteroduplex (double peaks) DNA species under conditions of partial thermal denaturation within each of the VDR exons are listed in Table III. The elution patterns for VDR PCR products corresponding to exons $1,6,7$ and 9 were highly similar with higher prevalence of double peaks of heteroduplex DNA among the PCa cases than controls. While, exons 2, 4, 5, 8 showed a similar elution patterns with 
Table IV. The correlation between the VDR exons and susceptibility to prostate cancer using phi-coefficient $(\phi)$.

\begin{tabular}{|c|c|c|c|c|c|c|c|c|}
\hline & Exon 1 & Exon 2 & Exon 4 & Exon 5 & Exon 6 & Exon 7 & Exon 8 & Exon 9 \\
\hline Exon 1 & 1 & & & & & & & \\
\hline Exon 2 & 0.056 & 1 & & & & & & \\
\hline Exon 4 & 0.095 & 0.227 & 1 & & & & & \\
\hline Exon 5 & 0.075 & 0.038 & 0.329 & 1 & & & & \\
\hline Exon 6 & 0.137 & -0.073 & -0.090 & 0.134 & 1 & & & \\
\hline Exon 7 & 0.070 & -0.003 & 0.335 & 0.579 & -0.167 & 1 & & \\
\hline Exon 8 & 0.095 & 0.227 & 1.000 & 0.329 & -0.090 & 0.335 & 1 & \\
\hline Exon 9 & 0.177 & -0.047 & 0.295 & 0.645 & 0.210 & 0.886 & 0.295 & 1. \\
\hline
\end{tabular}

Based on Table III data, exon 3 was excluded from analysis since there was only one sample with heteroduplex profile. Bold text indicates statistically significant a correlation $(p$-value $<0.05)$.

higher prevalence of double peaks among the controls than the cases. Exon 3 showed a distinct pattern of heteroduplex DNA in only one PCa case, therefore, it was excluded from any further analysis.

We further investigated the correlation among the VDR exons and susceptibility to PCa using phi-coefficient $(\phi)$ and logistic regression analysis. Phi-coefficient $(\phi)$ analysis showed that exons 5,7 , and 9 were moderately correlated $(\phi=0.579$, $0.645,0.886$; respectively). Exons 4 and 8 were perfectly correlated $(\phi=1)$ and they might be candidate exons associated with PCa risk (Table IV). The association of each VDR exon, as an independent variable without adjusting for any of the studied factors, with PCa risk was further investigated using logistic regression model. The significant results indicate that exon $2(\beta=-1.347, p<0.05)$, exon $4(\beta=-1.705, p<0.05)$ and exon $8(\beta=-1.705, p<0.05)$ had highly significant protective effects (Table V). On the other hand, exons 1, 6, 7, and 9 showed no statistically significant association with increased PCa risk $(p>0.05)$.

When all of the predictors were included in the regression equation based on the Backward Wald elimination method, only Exons 4 and 7 were the dominant factors; thus exons 2 and 8 were dropped out. The results were further investigated using logistic regression model to examine whether the effect of any of the exons (E) is modulated by another factor (e.g. Age, PSA level, family history). In particular, we assessed selected "E4 x E7"; "E4 x E7 x age"; "E4 x E7 x age x PSA"; and "E4 x E7 x age x PSA x family history" interactions in 4 models (Model, 1, Model 2, Model 3, and Model 4; respectively) that may include PCa as a factor. When a significant interaction was observed, we examined the effect of one factor at each level of the other factor (Table VI). Model 1 showed that exon 4 was a disease protective $(\beta=-2.206, \mathrm{OR}=0.110, p<0.05)$. Whereas, exon 7 was significantly associated with $\mathrm{PCa}$ risk $(\beta=1.150$, $\mathrm{OR}=3.159, p<0.05)$ and the heteroduplex profile of exon 7 was highly correlated with PCa risk. The outcome of models
2, 3 and 4 was inconsistent with model 1 data, exons 4 and 7 maintained the protective and risk associations with $\mathrm{PCa}$; respectively. Moreover, the heteroduplex profile of exon 7 was highly correlated with PCa risk, and as expected age and PSA level and family history were significantly associated with increasing prostate cancer risk $(p<0.05)$.

\section{Discussion}

Studies analyzing association of $V D R$ gene polymorphisms with cancer or other diseases, such as immune system related disorders, have been reported in the literature $(13,25)$. To date, more than 60 VDR polymorphisms have been discovered that are located in the promoter region, within and around exons 2-9, and in the 3' untranslated region (UTR) region $(26,27)$. Analysis of the importance of these $V D R$ polymorphisms for various diseases has proven difficult. As a result, only few polymorphisms of this large gene have been studied. Most of them are RFLP with an unknown functional effect (26). In some cases, it has been indicated that they may be linked to truly functional polymorphisms elsewhere in the $V D R$ gene (or in a nearby gene), which explains some of the associations observed (27). However, there is still controversy about the importance of $V D R$ polymorphisms for individual malignancies. There are many genetic studies that have examined the $V D R$ gene and PCa risk in which many reported statistically significant associations (5, 7), weaker associations $(4,28)$, or no associations (29-31) between common VDR variants and PCa risk. The VDR Bsm I polymorphism (rs5444410) does not affect the amino acid sequence of VDR, but many studies have suggested that it is closely related to PCa risk (32-35). Also, Taq I (rs731236) polymorphism has been associated with PCa risk (28-30, 32, 36-38). In the present study, we investigated the DHPLC elution patterns of PCR amplicons corresponding to VDR exons and their association with $\mathrm{PCa}$ risk. The elution patterns of $V D R$ exons 1, 6, 7 and 9 were all highly similar 
Table V. The association of each VDR exon, as an independent variable without adjusting to any of the studied factors, with prostate cancer risk using standard logistic regression model.

\begin{tabular}{lrlll}
\hline $\begin{array}{l}\text { Outcome } \\
\text { Cases/control }\end{array}$ & $\beta$-value & SD & $p$-Value & OR \\
\hline Constant & -0.105 & 0.188 & 0.574 & 0.900 \\
Exon 1 & 0.220 & 0.304 & 0.470 & 1.246 \\
Constant & 0.124 & 0.157 & 0.432 & 1.132 \\
Exon 2 & $\mathbf{- 1 . 3 4 7}$ & 0.533 & $\mathbf{0 . 0 1 1}$ & 0.260 \\
Constant & 0.847 & 0.230 & 0.000 & 2.333 \\
Exon 4 & $\mathbf{- 1 . 7 0 5}$ & 0.322 & $\mathbf{0 . 0 0 0}$ & 0.182 \\
Constant & 0.090 & 0.173 & 0.604 & 1.094 \\
Exon 5 & 0.412 & 0.335 & 0.218 & 0.662 \\
Constant & -0.057 & 0.150 & 0.707 & 0.945 \\
Exon 6 & 0.973 & 0.850 & 0.252 & 2.645 \\
Constant & -0.111 & 0.193 & 0.564 & 0.895 \\
Exon 7 & 0.217 & 0.300 & 0.470 & 1.242 \\
Constant & 0.847 & 0.230 & 0.000 & 2.333 \\
Exon 8 & $\mathbf{- 1 . 7 0 5}$ & 0.322 & $\mathbf{0 . 0 0 0}$ & 0.182 \\
Constant & -0.103 & 0.203 & 0.612 & 0.902 \\
Exon 9 & 0.172 & 0.296 & 0.560 & 1.188 \\
\hline
\end{tabular}

$\mathrm{SD}$, Standard deviation; OR, odd ratio. Bold text indicates a $p$-value less than 0.05 .

with higher prevalence of double peaks of heteroduplex DNA among the PCa cases than controls. While, exons 2, 4, 5 and 8 showed similar patterns with higher prevalence of double peaks among the controls than the cases. Our further analysis suggested that exon 7 is associated with PCa risk; whereas, exons 4 , and 8 are protective. These positive and negative association results are based on the DHPLC patterns and other PCa risk factors such as age, PSA level, and family history of PCa. Previously, we have reported an association of rs731236 (exon 9) and rs7975232 with PCa risk (15). In the analysis of clinical phenotypes, rs731236, rs1544410, and rs3782905 are strongly associated with high PSA level, whereas rs1544410 and rs2239185 show a statistically significant association with high Gleason score (15). A previous publication has reported that the Taq I (rs731236) polymorphism affects VDR transcriptional activity and mRNA stability, thus altering the abundance of VDR protein, and in turn affecting vitamin D levels (39).

Liu S. and colleagues (40) have conducted a meta-analysis to retrieve genetic association analyses of rs731236 and rs 1544410 polymorphisms with PCa from studies published between 2006 and 2016. Their findings suggest a significant association between rs731236 and PCa risk in Asians and African Americans, but rs1544410 was not associated with PCa under three genetic models.

In our previous study, we have found an association between Taq I, Apa I and rs2239185 with PCa risk (15),
Table VI. Logistic regression model to determine association of the exons and risk factors (age, PSA and family history) with prostate cancer risk (outcome).

\begin{tabular}{|c|c|c|c|c|}
\hline & Model 1 & Model 2 & Model 3 & Model 4 \\
\hline \multicolumn{5}{|l|}{ Exon 4} \\
\hline$\beta$-Value & -2.206 & -2.491 & -2.814 & -2.760 \\
\hline$p$-Value & 0.000 & 0.000 & 0.000 & 0.000 \\
\hline Odds ratio & 0.110 & 0.083 & 0.060 & 0.063 \\
\hline \multicolumn{5}{|l|}{ Exon 7} \\
\hline$\beta$-Value & 1.150 & 1.510 & 1.804 & 1.811 \\
\hline$p$-Value & 0.000 & 0.000 & 0.000 & 0.000 \\
\hline Odds ratio & 3.159 & 4.529 & 6.074 & 6.117 \\
\hline \multicolumn{5}{|l|}{ Age } \\
\hline$\beta$-Value & & 0.123 & 0.116 & 0.117 \\
\hline$p$-Value & & 0.000 & 0.000 & 0.000 \\
\hline Odds ratio & & 1.131 & 1.122 & 1.124 \\
\hline \multicolumn{5}{|l|}{ PSA } \\
\hline$\beta$-Value & & & 0.235 & 0.229 \\
\hline$p$-Value & & & 0.000 & 0.000 \\
\hline Odds ratio & & & 1.265 & 1.257 \\
\hline \multicolumn{5}{|l|}{ Fam History } \\
\hline$\beta$-Value & & & & 0.413 \\
\hline$p$-Value & & & & 0.000 \\
\hline Odds ratio & & & & 1.511 \\
\hline \multicolumn{5}{|l|}{ Constant } \\
\hline$\beta$-Value & 0.619 & -7.252 & -7.308 & -7.505 \\
\hline$p$-Value & 0.010 & 0.000 & 0.000 & 0.000 \\
\hline
\end{tabular}

Model 1: "prostate cancer x E4 x E7"; Model 2: "prostate cancer x E4 x E7 x age"; Model 3: "prostate cancer x E4 x E7 x age x PSA"; Model 4: "prostate cancer x E4 x E7 x age x PSA x family history. Exon, E; PSA, prostate-specific antigen.

while Oakley-Girvan et al. (41) did not find an association among Bsm I, Apa I, or Taq I and poly-A microsatellite with $\mathrm{PCa}$ risk in the family or case-control data.

Our previous haplotype analysis for SNPs in the VDR gene revealed that rs2239185 is in linkage disequilibrium with rs2289179 and Apa I, while Taq I and Apa I are in linkage disequilibrium and are located 80 bps apart. Furthermore, rs52853563 is in linkage disequilibrium with Bsm I and with rs4516035, rs10783218, and rs3782905. It has been reported that the Apa I, Taq I, Bsm I SNPs are all located in one block, which is thought to contain other variants at 3'-untranslated region of the VDR gene that may affect VDR expression by altering the mRNA stability and thus have an effect on vitamin D metabolism and activity $(42,43)$. However, the Taq I polymorphism is not functional but is in linkage disequilibrium with a poly-A microsatellite repeat in the 3' UTR that is thought to be important for the post-transcriptional regulation of gene expression. The SNP rs3782905 is in the DNA binding domain responsible for interaction with vitamin D response elements (VDREs) in target genes (44). 
In general, SNPs tend to be inherited in groups and these groups of SNPs and their various possible combinations might have a significant association with the disease phenotype. Haplotype analysis is likely to continue to play a key role in genetic epidemiology studies because it effectively captures both the joint marker correlations and the evolutionary history (45). Therefore, the DHPLC elution patterns of each exon could predict the risk of $\mathrm{PCa}$.

\section{Conclusion}

To our knowledge, this is the first study to evaluate the relation between the DHPLC elution patterns of VDR PCR amplicons and the risk of $\mathrm{PCa}$ in African American men. Further investigation of this association, in larger studies could reveal the usefulness of DHPLC analysis in fast screening and treatment, aiming to reduce the disease impact on health disparity, mainly in African American men.

\section{Disclosure}

The Authors have no personal or financial conflicts of interest and have not entered into any agreement that could interfere with our access to the data on the research, or upon our ability to analyze the data independently, to prepare manuscripts, and to publish them.

\section{Acknowledgements}

This work was supported by US Army Medical Research and Materiel Command (USAMRMC) [DAMD17-03-1-0069].

\section{References}

1 Haas GP, Delongchamps N, Brawley OW, Wang CY and de La Roza G: The worldwide epidemiology of prostate cancer: perspectives from autopsy studies. Can J Urol 15(1): 3866-3871, 2008.

2 Wong MCS, Goggins WB, Wang HHX, Fung FDH, Leung C, Wong SYS and Ng CF: Global Incidence an Mortality for Prostate Cancer: Analysis of Temporal Patterns and Trends in 36 Countries. Eur Urol 70(5): 862-874, 2016.

3 Shui I and Giovannucci E: Vitamin D status and cancer incidence and mortality. Adv Exp Med Biol 810: 33-51, 2014.

4 Schuurman, AG, Zeegers MP, Goldbohm RA and van den Brandt PA: A case-cohort study on prostate cancer risk in relation to family history of prostate cancer. Epidemiology 10(2): 192-195, 1999.

5 Ekman P, Pan Y, Li C and Dich J: Environmental and genetic factors: a possible link with prostate cancer. Br J Urol Suppl 2: 35-41, 1997.

6 Gupta D, Lammersfeld CA, Trukova K and Lis CG: Vitamin D and prostate cancer risk: a review of the epidemiological literature. Prostate Cancer Prostatic Dis 12(3): 215-226, 2009.

7 Carter BS, Bova GS, Beaty TH, Steinberg GD, Childs B, Isaacs WB and Walsh PC: Hereditary prostate cancer: epidemiologic and clinical features. J Urol 150(3): 797-802, 1993.
8 Kanaan YM, Beyene D, Daremipouran M, Mireku-Boateng A, Williams R, Jackson A, Bonney G, Apprey V, Daniel M, Wutoh A, Rohan JA, Ricks-Santi L and Copeland RL: Association of cumulative ultraviolet radiation exposure with prostate cancer in a case-control study of African American men. Open Prost cancer J 5: 8-14, 2012.

9 Ordonez-Moran P, Larriba MJ, Pendas-Franco N, Aguilera O, Gonzalez-Sancho JM and Munoz A: Vitamin D and cancer: an update of in vitro and in vivo data. Front Biosci 10: 2723-2749, 2005.

10 Verstuyf A and Bouillon R: Vitamin D and cancer. Cell Cycle 12: 743-752, 2013

11 Giovannucci E: The epidemiology of vitamin D and cancer incidence and mortality: a review. Cancer Causes Control 16(2): 83-95, 2005.

12 Blazer DG III/3rd, Umbach DM, Bostick RM and Taylor JA: Vitamin D receptor polymorphisms and prostate cancer. Mol Carcinog 27(1): 18-23, 2000.

13 Correa-Cerro L, Berthon P, Haussler J, Bochum S, Drelon E, Mangin P, Fournier G, Paiss T, Cussenot $O$ and Vogel W: Vitamin D receptor polymorphisms as markers in prostate cancer. Hum Genet 105(3): 281-287, 1999.

14 Gsur A, Madersbacher S, Haidinger G, Schatzl G, Marberger M, Vutuc $\mathrm{C}$ and Micksche M: Vitamin D receptor gene polymorphism and prostate cancer risk. Prostate 51(1): 30-34, 2002.

15 Jingwi EY, Abbas M, Ricks-Santi L, Winchester D, Beyene D, Day A, Naab TJ, Kassim OO, Dunston GM, Copeland RL Jr and Kanaan YM: Vitamin D receptor genetic polymorphisms are associated with PSA level, Gleason score, and prostate cancer risk in African-American men. Anticancer Res 35(3): 1549-1558, 2015.

16 Gandini S, Gnagnarella P, Serrano D, Pasquali E and Raimondi S: Vitamin D receptor polymorphisms and cancer. Adv Exp Med Biol 810: 69-105, 2014.

17 Ordóñez Mena JM and Brenner H: Vitamin D and cancer: an overview on epidemiological studies. Adv Exp Med Biol 810: 17-32, 2014.

18 Huang QQ, Liao YY, Ye XH, Fu JJ and Chen SD: Association between VDR polymorphisms and breast cancer: an updated and comparative meta-analysis of crude and adjusted odd ratios. Asian Pac J Cancer Prev 15(2): 847-853, 2014.

19 Hou W, Wan X and Fan J: Variants Fok1 and Bsm1 on VDR are associated with the melanoma risk: evidence from the published epidemiological studies. BMC Genet 16: 14, 2015.

20 Chen WY, Bertone-Johnson ER, Hunter DJ, Willett WC and Hankinson SE: Associations between polymorphisms in the vitamin D receptor and breast cancer risk. Cancer Epidemiol Biomarkers Prev 14(10): 2335-2339, 2005.

21 Ntais C, Polycarpou A and Loannidis JP: Vitamin D receptor gene polymorphisms and risk of prostate cancer: a metaanalysis. Cancer Epidemiol Biomarkers Prev 12(12): 1395-1402, 2003.

22 Hayes VM, Severi G, Padilla EJ, Eggleton SA, Southey MC, Sutherland RL, Hopper JL and Giles GG: Genetic variants in the vitamin D receptor gene and prostate cancer risk. Cancer Epidemiol Biomarkers Prev 14: 997-999, 2005.

23 Hecker KH, Asea A, Kobayashi K, Green S, Tang D and Calderwood SK: Mutation detection in the human HSP70B9 gene by denaturing high performance liquid chromatography. Cell Stress Chaperon 5(5): 415-424, 2000. 
24 Beyene D, Daremipouran M, Apprey V, Williams R, Ricks-Santi L, Kassim OO, Naab TJ, Kanaan YM and Copeland RL: Use of tanning potential as a predictor for prostate cancer risk in African-American men. In Vivo 28(6): 1181-1187, 2014.

25 Berndt SI, Dodson JL, Huang WY and Nicodemus KK: A systemic review of vitamin D receptor gene polymorphisms and prostate cancer risk. J Urol 175(5): 1613-1623, 2006.

26 Kostner K, Denzer N, Muller CS, Klein R, Tilgen W and Reichrath J: the relevance of vitamin D receptor (VDR) gene polymorphisms for cancer: a review of the literature. Anticancer Res 29(9): 3511-3536, 2009.

27 Uitterlinden AG, Fang Y, van Meurs JB, Pols HA and Van Leeuwen JP: Genetics and biology of vitamin D receptor polymorphisms. Gene 338(2): 143-156, 2004.

28 Smith JR, Freijie D, Carpten JD, Gronberg H, Xu J, Isaacs SD, Brown stein MJ, Bova GS, Guo H, Bujnovszky P, Damber JE, Bergh A, Emanuelsson M, Kallioniemi OP, Walker-Daniels J, Bailey-Wilson JE, Meyers DA, Walsh PC, Collins FS, Trent JM and Isaacs WB: Major susceptibility locus for prostate cancer on chromosome 1 suggested by a genome-wide search. Science 274(5291): 1371-1374, 1996.

29 Xu J, Meyers D, Freije D, Isaacs S, Wiley K, Nusskern D, Ewing C, Wilkens E, Bujnovszky P, Bova GS, Walsh P, Isaacs W, Schleutker J, Matikainen M, Tammela T, Visakorpi T, Kallioniemi OP, Berry R, Schaid D, French A, McDonnell S, Schroeder J, Blute M, Thibodeau S, Grönberg H, Emanuelsson M, Damber JE, Bergh A, Jonsson BA, Smith J, Bailey-Wilson J, Carpten J, Stephan D, Gillanders E, Amundson I, Kainu T, Freas-Lutz D, Baffoe-Bonnie A, Van Aucken A, Sood R, Collins F, Brownstein $\mathrm{M}$ and Trent J: Evidence for a prostate cancer susceptibility locus on the X chromosome. Nat Genet 20(2): 175-179, 1998.

30 Berthon P, Valeri A, Cohen-Akenine A, Drelon E, Paiss T, Wöhr G, Latil A, Millasseau P, Mellah I, Cohen N, Blanché H, Bellané-Chantelot C, Demenais F, Teillac P, Le Duc A, de Petriconi R, Hautmann R, Chumakov I, Bachner L, Maitland NJ, Lidereau R, Vogel W, Fournier G, Mangin P and Cussenot O: Predisposing gene for early-onset prostate cancer, localized on chromosome 1q42.2-43. Am J Hum Genet 62(6): 1416-1424, 1998.

31 Cheteri MB, Stanford JL, Friedrichsen DM, Peters MA, Iwasaki L, Langlois MC, Feng Z and Ostrander EA: Vitamin D receptor gene polymorphisms and prostate cancer risk. Prostate 59(4): 409-418, 2004.

32 Ingles SA, Ross RK, Yu MC, Irvine RA, La Pera G, Haile RW and Coetzee GA: Association of prostate cancer risk with genetic polymorphisms in vitamin D receptor and androgen receptor. J Natl Cancer Inst 89(2): 166-170, 1997.

33 John EM, Schwartz GG, Koo J, Van Den Berg D and Ingles SA: Sun exposure, vitamin D receptor gene polymorphisms and risk of advanced prostate cancer. Cancer Res 65(12): 5470-5479, 2005 .
34 Young AR and Walker SL: UV radiation, vitamin D and human health: an unfolding controversy introduction. Photochem Photobiol 81(6): 1243-1245, 2005.

35 Bodiwala D, Luscomb CJ, French ME, Liu S, Saxby MF, Jones PW, Ramachandran S, Fryer AA and Strange RC: Susceptibility to prostate cancer: studies on interactions between UVR exposure and skin type. Carcinogenesis 24(4): 711-717, 2003.

36 Clinton SK and Giovannucci E: Diet, nutrition, and prostate cancer. Annu Rev Nutr 18: 413-440, 1998.

37 Mikhak B, Hunter DJ, Spiegelman D, Platz EA, Hollis BW and Giovannucci E: Vitamin D receptor (VDR) gene polymorphisms and haplotypes, interactions with plasma 25-hydroxyvitamin D and 1,25-dihydroxyvitamin D, and prostate cancer risk. Prostate 67(9): 911-123, 2007.

$38 \mathrm{Li} \mathrm{H}$, Stampfer MJ, Hollis JB, Mucci LA, Gaziano JM, Hunter D, Giovannucci EL and Ma J: A prospective study of plasma vitamin D metabolites, vitamin D receptor polymorphisms, and prostate cancer. PLoS Med 4(3): e103, 2007.

39 Morrison NA, Qi JC, Tokita A, Kelly PJ, Crofts L, Nguyen TV, Sambrook PN and Eisman JA: Prediction of bone density from vitamin D receptor alleles. Nature 367: 284-287, 1994.

40 Liu S, Cai H, Cheng W, Zhang H, Pan Z and Wang D: Association of VDR polymorphisms (Tag I and Bsm I) with prostate cancer: a new meta-analysis. J Int Med Res 45(1): 3-10, 2017.

41 Oakley-Girvan I, Feldman D, Eccleshall TR, Gallagher RP, Wu AH, Kolonel LN, Halpern J, Balise RR, West DW, Paffenbarger RS Jr. and Whittemore AS: Risk of early-onset prostate cancer in relation to germ line polymorphisms of the vitamin D receptor. Cancer Epidemiol Biomarkers Prev 13: 1325-1330, 2014.

42 Watanabe M, Fukutome K, Murata M, Uemura H, Kubota Y, Kawamura J and Yatani R: Significance of vitamin D receptor gene polymorphism for prostate cancer risk in Japanese. Anticancer Res 19(5C): 4511-4514, 1999.

43 Ogunkolade WB, Boucher BJ, Bustin SA, Burrin JM, Noonan $\mathrm{K}$ and Mannan N: Vitamin D metabolism in peripheral blood mononuclear cells is influenced by chewing "betel nut" (Areca catechu) and vitamin D status. J Clin Endocrinol Metab 91: 2612-2617, 2006.

44 Holt SK, Kwon EM, Peters U, Ostrander EA and Stanford JL: Vitamin D pathway gene variants and prostate cancer risk. Cancer Epidemiol Biomarkers Prev 18: 1929-1933, 2009.

45 Schaid DJ: Evaluating associations of haplotypes with traits. Genet Epidemiol 27: 348-364, 2004.

Received June 22, 2017

Revised August 11, 2017

Accepted September 6, 2017 